\title{
ASSESSMENT OF QUALITY AND FOOD SAFETY OF VEGETABLE OILS PRODUCED ON THE BASE OF WILD BERRIES OF KAZAKHSTAN'S FOREST AREAS \\ G.S. AIDARKHANOVA ${ }^{1}$, Z. I. SATAYEVA ${ }^{1}$, A. V. EBEL ${ }^{1}$ \\ M. T. JAKANOVA ${ }^{2}$ \\ O. V. VOLOSIANKO \\ T. M. SEILKHANOV ${ }^{4}$ \\ ${ }^{1}$ S.Seifullin Kazakh Agrotechnical University \\ ${ }^{2}$ Republic diagnostic center Corporate fund «University Medical Center» \\ Nazarbayev University \\ ${ }^{3}$ National University of Life and Environmental Sciences of Ukraine \\ ${ }^{4}$ Sh.Ualikhanov Kokshetau State University \\ E-mail: lybenko55@gmail.com
}

https://doi.org/https://doi.org/10.31548/dopovidi2020.05.001

Abstract. Many species of forest plants in combination with vegetable oils are the sources of new types of functional products with increased biological efficiency. In respect that the high demand for vegetable oils among the population and industry, the growing anthropogenic pressure on various components of the natural environment, the goal of the research was to create oil mixtures based on sunflower oil and wild berries selected in the forest areas of Kazkhstan's regions, assess their quality and food safety. The base of the oil mixture was sunflower oil obtained from sunflower seeds by the "cold squeeze" method. Wild berries selected from forest areas of northern (Elaeagnus rhamnoides (L.) A. Nelson) and eastern (Rosa majalis Herrm., Vaccinium myrtillis L.) of Kazakhstan were used as bio-additives. In the obtained oil mixtures, the basic parameters of their qualitative and quantitative composition were studied. It was found that by density (917-918), refractive index (1,473), acid number (1,4 mg KOH/g), iodine number (130-132 g J2/100), saponification number (188 $\mathrm{mg} / \mathrm{g})$ of the tested oil mixtures they correspond to unrefined vegetable oil of higher grade.

The content of heavy metals ( $\mathrm{Pb}, \mathrm{As}, \mathrm{Cd}, \mathrm{Cu}, \mathrm{Zn}, \mathrm{Mg}$ ) and radionuclides $\left({ }^{90} \mathrm{Sr}\right.$, ${ }^{137} \mathrm{Cs}$ ) does not exceed the maximum permissible concentrations and meets the requirements of regulatory documents and standards. In samples of vegetable oils, the amount of oleic acid $(52,21 \%)$, linoleic acid $(28,97 \%)$ is determined, which are within the normal range, although they are adjacent to the levels of the upper limits. NMR spectroscopy confirmed that the optimal ratio of $\omega-6$ and $\omega-3$ polyunsaturated fatty acids in the composition of the studied vegetable oils correspond to their name in the ratio of monounsaturated and polyunsaturated fatty acids.

Keywords: wild berries, sunflower oil, unrefined oils, heavy metals, radionuclides, physicochemical parameters, fatty acid composition, NMR spectroscopy, spectra, proton signals 
Айдарханова Г. С., Сатаева Ж. І., Ебель А. В., Джаканова М., Волосянко О. В., Сейлханов Т. М.

Vegetable oils take a significant place among important food products in the human diet. They are a valuable multivitamin product for the food and pharmaceutical industry due to the content of effective biologically active organic components and mineral substances [1].

Some oils are raw materials for the creation of food additives, medicinal and cosmetic products based on the use of components of non-wood forest products.

In many regions of the world, forest products are the main source of wood, animal feed, additional components of food from forest berries, nuts, medicinal herbs and other food products that provide seasonal income [2].

The study of the plant resources in forest areas forms part of the broader field of the use of natural plant resources in various sectors of agriculture, food industry, medicine and pharmacology. Methods for rational and sustainable use of various types of non-wood forest resources are currently being developed in many countries: the regulatory and methodological framework for assessing their reserves is being improved and supplemented, the features of biology and ecology of various types of raw plants are being studied, new technologies for obtaining new products, introducing studied and poorly studied species, etc. are being developed [3].

In Kazakhstan, the total area of forests occupies about $10 \%$ of the total land area of the republic. The timber industry of the country is dominated by the woodworking industry. Harvesting of by-products (wild berries, edible fungi, medicinal plants, cones, spruce legs, hay forest edges, etc.) occurs spontaneously, without taking into account the scientific foundations of the state of forest ecosystems [4].

The oil and fat industry of Kazakhstan is currently demonstrating intensive development processes. In the period from 2009 to 2019, the area of oilseeds increased from 1,2 million hectares to 2,9 million hectares. Kazakhstan produces various species of oilseeds (sunflower, flax, safflower, rapeseed, mustard) and their processing products. There are about 52 enterprises for the processing of oilseeds with a total capacity 2 million tons per year [5].It is common knowledge that many types of forest plants in combination with vegetable oils are sources of new types of functional products with increased biological efficiency [6].

Some authors noted that natural and climatic conditions essentiallyinfluence on the quality of vegetable oil [7]. Due to the anthropogenic disturbance of the natural environment in the places of natural phytocenoses growth, representatives of which are used for the production of vegetable oils, there are data on accumulation in fruits and other organs of heavy metals and radionuclides.Therefore, it is relevant to assess the environmental safety of raw materials, which are harvested in forest areas and can be used in industrial 
Айдарханова Г. С., Сатаева Ж. І., Ебель А. В., Джаканова М., Волосянко О. В., Сейлханов Т. М.

technologies for the production of vegetable oils $[8,9]$.

In the composition of vegetable oils, the main components are polyunsaturated fatty acids of the families $\omega-3, \omega-6$ and $\omega-9$, and other biologically active components [10]. A very important problem is the accurate analysis of the biochemical, phytochemical and fatty acid composition of the obtained oils. Analytical studies of organic acids use chemical and physical methods that are time-consuming and raw materials, as they require multi-stage analyses and large volumes of samples. Among modern methods, methods of gas chromatography, thin-layer chromatography, ultra-violet (UV) -, infra-red (IR) - spectroscopy are used to analyze and identify the fatty acid composition of vegetable oils. Among specialists, there is an active search for methods of analyzing and identifying the fatty acid composition of vegetable oils for wide use. In some cases, when separating complex oil mixtures, it is possible to match the retention times of individual components, which requires the use of more sensitive methods [11]. The method of nuclear magnetic resonance spectroscopy (NMR spectroscopy) has been widely used among non-destructive methods for the study of vegetable oils. This method makes it possible to quickly determine the content of fatty acids and their ratio, including unsaturated fatty acids. NMR spectroscopy based on known chemical shifts of carbon atoms of acid groups of fatty acids' glycerides enables to quantify the composition of unsaturated glycerides` fatty acids (oleic, linoleic and linolenic acids) and determine the type of vegetable oil without additional sample preparation [12-16]. Taking into account the high demand for vegetable oils among the population and industry, the growing anthropogenic pressure on various components of the natural environment, the goal of the research was to assess the quality and food safety of vegetable oils obtained from the use of wild berries selected in the forest territories of Kazakhstan`s regions.

\section{Research materials and methods.}

The material for the study was sunflower oil "Kazakhstan-5" breed, grown in the East Kazakhstan region, selected during ripening and mass harvests by the population. Cold oil squeezing was prepared under laboratory conditions for analysis according to "GOST 30418-96. Vegetable oils received unrefined sunflower and linseed oils according to standard requirements [17].

The collection of wild berries for compiling mixtures (rosehips, sea buckthorn, blueberries) was carried out during the organization of the expedition in 2019 in the forest territories of Akmola and East Kazakhstan regions. Figure 1 shows the location of field research and harvesting of forest berries. In the field, the geobotanical features of phytocenoses were studied using the route method, resource reserves for harvests were determined. When 
Айдарханова Г. С., Сатаева Ж. І., Ебель А. В., Джаканова М., Волосянко О. В., Сейлханов Т. М.

describing plant communities with the participation of the research object, geobotanical methods were used with a visual assessment of the number of individuals on the scale of G. Drude [18]. In laboratory conditions, concentrations of heavy metals (cadmium, arsenic, mercury, lead, cobalt, copper, manganese) were determined by atomic absorption spectroscopy in berries in accordance with standard requirements
(ST RK GOST R 51301-05) [19]. The contents ${ }^{90} \mathrm{Sr},{ }^{137} \mathrm{Cs}$ in the fruits which were dried up to an air-dry state and incinerated at temperature up to $420^{\circ} \mathrm{C}$ were studied by gamma spectrometric method on the device "Progress" [20]. Based on the obtained results, a comparative analysis of compliance of fruits with sanitary and hygienic standards [21] was carried out and their food safety was evaluated.

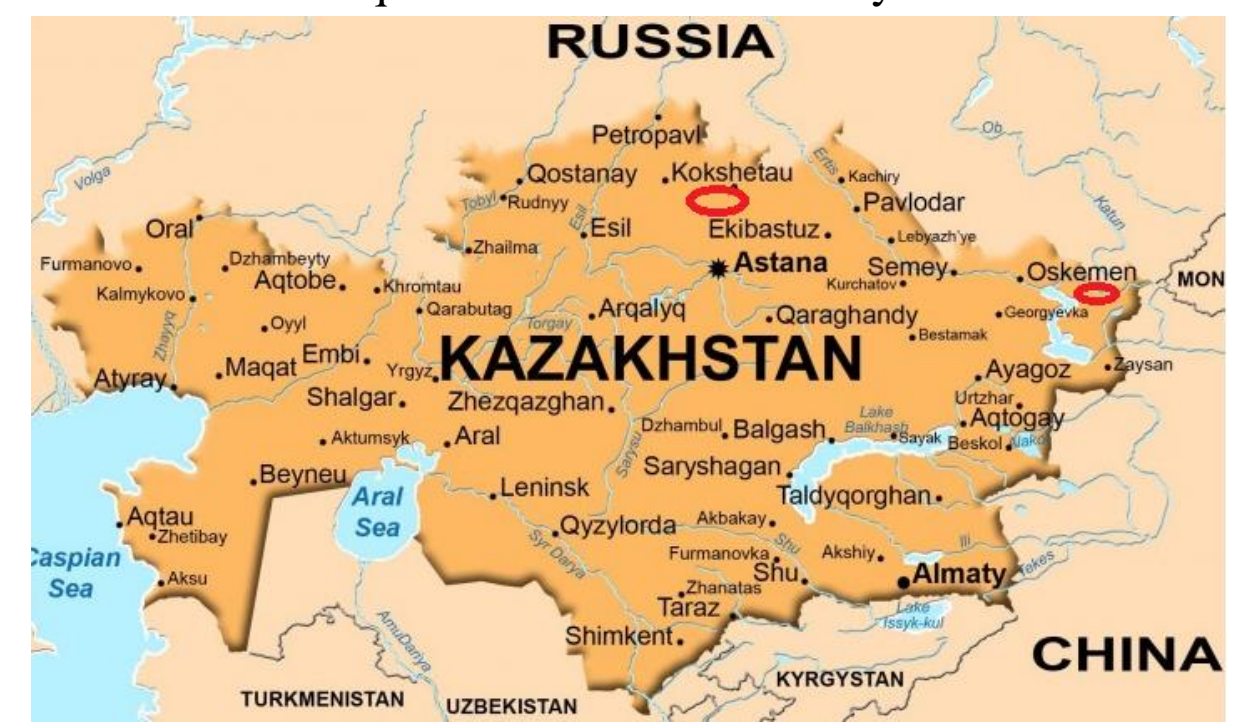

Figure 1.Location of research sites

On the basis of sunflower oil, we obtained varieties of a mixture of vegetable oils using forest berries. Preparation of assortment of vegetable oils is carried out by the method of raw materials extraction. To do this, purified sunflower oil heated to a temperature 45$50^{\circ} \mathrm{C}$ was mixed with berries in a volume of $30 \%$ of the total volume in glassware. The mixture was thoroughly mixed, placed on a water bath at a temperature $50^{\circ} \mathrm{C}$, covered with a paper bag, then covered (the resulting condensate would be absorbed into the paper). The mixture was heated for 3 hours, shaking the mixture periodically. The macerate was then stirred and completely cooled. The heating, mixing and extraction process was repeated once more. The period of complete extraction of wild berries active substances lasted 10 days in a dark cool place. After settling, the raw materials were squeezed, filtered and the finished oil extract was poured into bottles from dark glass, with a tightly closing lid.

Quality characteristics of sunflower were determined by density [22], refractive index [23]. To determine the suitability of the oil for food purposes and characterized by the free fatty acid content in the oil, the acid number was 
Айдарханова Г. С., Сатаева Ж. І., Ебель А. В., Джаканова М., Волосянко О. В., Сейлханов Т. М.

studied by titration of the oil sample with an alkali solution in the presence of the phenolphthalein indicator according to [24]. An iodine number according to [25] was determined to assess the degree of fat unfavorability, its ability to oxidize, dry, and hydrogen addition. The procedure described in [26] was used to analyze the saponification number.

The qualitative and quantitative composition of polyunsaturated fatty acids of vegetable oils with different content of $\omega-6$ and $\omega-3$ fatty acids was studied on an NMR spectrometer. Ranges of nuclear magnetic resonance ${ }^{1} \mathrm{H}$ and ${ }^{13} \mathrm{C}$ were removed on a spectrometer of JNM-ECA Jeol 400 (frequency 399,78 and $100,53 \mathrm{MHz}$ respectively) with $\mathrm{CDCl} 3$ solvent use. Spectra were taken in ampoules $5 \mathrm{~mm}$ wide, the total volume of the solution 0,6 $\mathrm{ml}$, the concentration of the substance in the deuterated solvent was 5-10\%. Chemical shifts are measured with respect to signals of residual protons or carbon atoms of deuterized chloroform. For quantitative analysis of the samples, $0,6 \mathrm{ml}$ of vegetable oil was dissolved in $0,3 \mathrm{ml}$ of $\mathrm{CDCl} 3$. Chemical shifts of proton signals of the compounds were determined by the chloroform signal (CHCl3, $\delta=7,27$ p.p.m.) that was present in the deuterized solvent. Spectral recording was performed taking into account the relaxation of protons of all compounds. When recording spectra of ${ }^{13} \mathrm{C}$, the solvent signal $(\delta=77,7 \mathrm{~m}$.) was used as a reference. For quantitative analysis, spectra were recorded with suppression of interaction with protons and using pulse sequences that excluded the manifestation of the Overhauser effect. To reduce the time of spin-lattice relaxation, chromium trisacetylacetonate was added to the solutions. Since the relaxant slightly changes the chemical shifts of the nuclei ${ }^{13} \mathrm{C}$ components of essential oils, spectra of available individual acids present in these oils were recorded for control: oleic, linoleic, linolenic, palmitic and stearic. Signal assignment was performed using the Polarization Transfer Spectrum Recording (DEPT) technique. Statistical processing of the obtained results of laboratory-field experiments was carried out using Microsoft Excel. Taking into account the Fischer-Student test, recorded changes in indicators were considered reliable in $\mathrm{p} \leq 0,05$.

Results and discussion. The surveyed forest territories of East Kazakhstan and Akmola regions are exclusively representative areas, distinguished by climate originality, geomorphological and botanicalgeographical features. Kazakhstan Altai is a mountainous country represented by a system of ridges of the southern and southwestern part of Altai, extending from south to north and from west to east for about $400 \mathrm{~km}$, which is a part of the southwestern periphery of the AltaiSayan mountain system [27] with a rich composition of flora and fauna. The territory of the Burabay State National Natural Park is a combination of islands 
Айдарханова Г. С., Сатаева Ж. І., Ебель А. В., Джаканова М., Волосянко О. В., Сейлханов Т. М.

of low-mountain pine forests with large lakes surrounded by steppe spaces as a part of the Kazakh shallow forest. Vegetation in the natural park is represented by forest, steppe, meadow, swamp and salt marsh types, the flora has about 800 plant species. The animal world is represented by an abundance of fish- and ornithofauna [28, 29]. During the period of field research, we selected rosehips and blueberries in the forest territories of East Kazakhstan. The examined community of rosehips (Rosa majalisHerrm.) is located in the East Kazakhstan region, at the foot of Sarymsakty range, in the valley of the Solonechnayariver, in the neighborhood ofTopkain $\left(49.185556^{\circ} \mathrm{N}, 85.503611^{\circ}\right.$ E) (Fig. 1), height - $622 \mathrm{~m}$ above sea level. The relief is presented in the form of ravine hollow on a leveled area, along the indigenous banks of the Solonechnayariver. The microrelief of the site is heterogeneous, formed by ledges and promontory of small gutters. Floodplain soils, meadow chernozems with a significant layer of nanoscale humus, the underlying layer is a river pebble. The projective coating of the soil cover is $85-90 \%$, the thickness of the layer is $1,5-2 \mathrm{~cm}$.

Blueberries (Vaccinium myrtillis L.) were picked up on the territory of the Pikhtovsky forestry (Butakovsky forestry, 38 quarter, 40 exiles) of the East Kazakhstan region $\left(50^{0} 22^{1} 25^{\mathrm{II}} \mathrm{N}\right.$ $\left.83^{0} 53^{\mathrm{I}} 54^{\mathrm{II}} \mathrm{E}\right)$. The total area of the survey was 30 hectares. The terrain is mountainous. Berry glades are located at an altitude in the range of $380-1171 \mathrm{~m}$ above sea level.

The fruits of sea buckthorn (Elaeagnus rhamnoides (L.) A. Nelson) were picked up on the northeastern shore of Lake Shchuchye (Shortankol), which is located northwest of Shchuchinsk city, in the Burabai district, Akmola region, Republic of Kazakhstan $\left(53.00577^{\circ} \mathrm{N}\right.$, $\left.70.19545^{\circ} \mathrm{E}\right)$. Height above sea level is $359 \mathrm{~m}$. This territory belongs to the Kokshetau Upland of the Central Kazakhstan shallow settlement [29]. The lake is a part of the Kokshetau Lakes group and is located within the territory of the Burabay State National Natural Park, Barmashinsky Forestry. The terrain is heterogeneous, weakly wavy ceded. Soils of meadow and swamp chernozems, closer to the water area, narrow lake bands of fluvisoli form. Sea buckthorn is a part of thickened treebush formations with a fullness of plantations 09-1. The surveyed population covers an area of about 2,5 hectares and is placed in a narrow strip of 50-70 $\mathrm{m}$ along the coastline, where the degree of humidification increases significantly.

The ecological safety of forest berries has been assessed by the indicators of their contamination with heavy metals and radionuclides (Table 1). The results analysis of the accumulation of heavy metals in the fruits of wild berries showed that for all the studied elements $\mathrm{Pb}, \mathrm{As}, \mathrm{Cd}, \mathrm{Cu}, \mathrm{Zn}$, $\mathrm{Mg}$ there were no exceedances of the maximum permissible concentrations. It 
Айдарханова Г. С., Сатаева Ж. І., Ебель А. В., Джаканова М., Волосянко О. В., Сейлханов Т. М.

should be noted that only the contamination value $\mathrm{Zn}(8,7-9,0 \mathrm{mg} / \mathrm{kg})$ is close to the upper limit of permissible levels $(10,0 \mathrm{mg} / \mathrm{kg})$.

In the region of eastern Kazakhstan, environmental monitoring of radionuclide contamination is relevant due to the fact that the territory of the former Semipalatinsk test site is located nearby. It was shown that the specific activity of forest berries is 5,4 times lower in ${ }^{90} \mathrm{Sr}$ than permissible levels, and
45,7 times lower in ${ }^{137} \mathrm{Cs}$. Thus, wild berries used for the preparation of oil mixtures are environmentally safe for wide use due to the low concentration of heavy metals and radionuclides. The very low levels of accumulation of heavy metals and radionuclides in forest berries are due to the absence of anthropogenic sources of pollution. Elaeagnus rhamnoides (L.) A. Nelson grows in a specially protected area, where all types of pollution are excluded.

\section{Average values of heavy metals and radionuclides content in berries}

\begin{tabular}{|l|c|c|c|c|c|c|l|l|}
\hline \multirow{2}{*}{ Berries`names } & \multicolumn{9}{|c|}{ Heavy metals, (mg/kg) } & \multicolumn{2}{|l|}{$\begin{array}{l}\text { Radionuclides, } \\
(\mathrm{Bq} / \mathrm{kg})\end{array}$} \\
\cline { 2 - 10 } & $\mathrm{Pb}$ & $\mathrm{As}$ & $\mathrm{Cd}$ & $\mathrm{Cu}$ & $\mathrm{Zn}$ & $\mathrm{Mg}$ & ${ }^{90} \mathrm{Sr}$ & ${ }^{137} \mathrm{Cs}$ \\
\hline $\begin{array}{l}\text { RosamajalisHerr } \\
\text { m. }\end{array}$ & 0,031 & 0,016 & 0,0035 & 4,0 & 8,7 & 30,7 & 8,8 & 1,9 \\
\hline $\begin{array}{l}\text { Vacciniummyrtill } \\
\text { isL. }\end{array}$ & 0,032 & 0,016 & 0,030 & 3,4 & 9,0 & 35,8 & 3,99 & 1,41 \\
\hline $\begin{array}{l}\text { Elaeagnusrhamn } \\
\text { oides(L.) } \\
\text { A.Nelson }\end{array}$ & 0,031 & 0,0018 & 0,0044 & 3,8 & 8,8 & 36,1 & 11,3 & 3,5 \\
\hline \begin{tabular}{l} 
MPC \\
\hline
\end{tabular} & 0,4 & 0,2 & 0,03 & 5,0 & 10,0 & - & 60,0 & 160,0 \\
\hline
\end{tabular}

Table 2 shows the research results of physical and chemical parameters of unrefined sunflower oil and obtained mixtures with addition of rosehips, blueberries, sea buckthorn. Performance

of quality assessment of production (technological) operations in the production of vegetable oils is estimated at the production stage according to physicochemical indicators.

\section{Quality characteristics of unrefined sunflower oil and its mixtures from} wild berries

\begin{tabular}{|l|c|c|c|c|}
\hline \multicolumn{1}{|c|}{ Indicator name } & Sunflower oil & $\begin{array}{c}\text { Sunflower oil } \\
\text { with rosehips }\end{array}$ & $\begin{array}{c}\text { Sunflower oil } \\
\text { with sea } \\
\text { buckthorn }\end{array}$ & $\begin{array}{c}\text { Sunflower oil } \\
\text { with } \\
\text { blueberries }\end{array}$ \\
\hline Density & & 918 & 918 & 917 \\
\hline Refractive index & 1,473 & 1,473 & 1,473 & 1,473 \\
\hline Acid number, $\mathrm{mg} \mathrm{KOH/g}$ & 1,4 & 1,4 & 1,4 & 1,4 \\
\hline Iodinenumber, $\Gamma \mathrm{J}_{2} / 100$ & 132 & 131 & 130 & 130 \\
\hline $\begin{array}{l}\text { Saponificationvalue, } \\
\text { mg/g }\end{array}$ & 188 & 188 & 188 & 188 \\
\hline
\end{tabular}


Айдарханова Г. С., Сатаева Ж. І., Ебель А. В., Джаканова М., Волосянко О. В., Сейлханов Т. М.

As can be seen from the data of Table 2, physicochemical indices of the tested vegetable oils correspond to unrefined sunflower oil of higher grade, since they meet the requirements of regulatory documents [22-26]. The production of high-quality vegetable oils is due to the applied technology, which was based on the method of "cold" pressing. Thanks to the gentle processing of oil-containing raw materials, this method is effective for producing oils from sunflower seeds and mixtures from wild berries, which provide the release of high-quality oil with a minimum amount of related substances.
In order to study the resistance of oils to oxidation, we studied the composition of fatty acids of the main sunflower oil obtained by the "cold" pressing method, which is considered promising in terms of preserving the native properties of oils. The main initial criterion for the quality of food fats are fatty acids. Fatty acids of vegetable oils and fats significantlydiffer in length of carbon chain, number and position of double bonds in it, spatial configuration [26]. These parameters determine the physical, chemical and biological properties. The research results of fatty acid composition of vegetable oils are summarized in Table 3.

\section{Table3. Fatty acid composition in vegetable oils}

\begin{tabular}{|l|c|c|}
\hline \multicolumn{1}{|c|}{ Acids` name } & $\begin{array}{c}\text { Norms, } \\
\%\end{array}$ & Sun flower oil, \% \\
\hline C 4:0 Oleic & - & 9,01 \\
\hline C 14:0Myristic & to 0,1 & 0,05 \\
\hline C 10:0 Palmitic & $4,0-5,5$ & 5,25 \\
\hline C16:1 Palmitooleic & to 0,1 & 0,03 \\
\hline C 17:0 Heptadecoic & to 0,1 & 0,07 \\
\hline C 18:0 Stearic & $2,1-5,0$ & 4,04 \\
\hline C 18:1 Olein & $43,1-71,8$ & 52,21 \\
\hline C 18:2 Linoleic & $18,7-45,3$ & 28,97 \\
\hline C 18:3 Linolenic & - & 0,1 \\
\hline C 20:0 Arachic & $0,2-0,4$ & 0,09 \\
\hline C 22:0 Behenic & $0,6-1,1$ & 0,1 \\
\hline C24:0 Lignoceric & to 0,4 & 0,08 \\
\hline
\end{tabular}

The data given in Table 3 showed that in sunflower oil samples, the amounts of palmitic, stearic acid were $5,2 \%$ and $4,04 \%$, respectively. It should be noted that these types of acids are within normal limits, although they are adjacent to the levels of the upper limits.

By NMR spectrometry, we supplemented the characteristics of the qualitative and quantitative composition of polyunsaturated fatty acids of vegetable oils with different contents of $\omega-6$ and $\omega-3$ fatty acids. The most characteristic signals had carbons at double bonds, which made it possible to easily identify chemical compounds. In more detail, the chemical shifts of the acyl chain double bond regions of fatty 
acids of the combination of vegetable oils on carbon spectra are shown in Figures 2-5. The range of nuclear magnetic resonance $1 \mathrm{H}$ consisted of a number of multiplets.

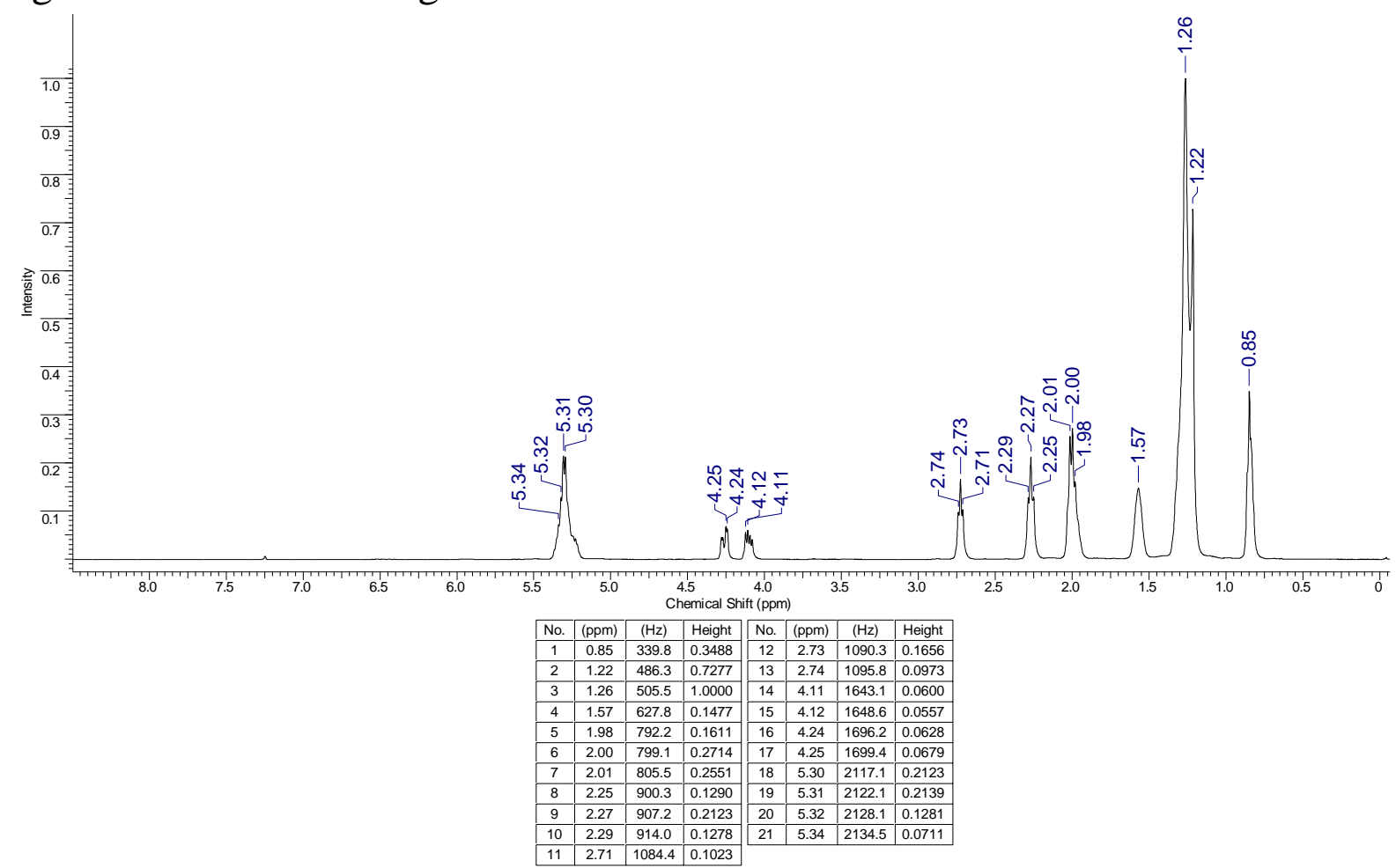

\section{Figure2 - ${ }^{1}$ HNMR - spectra of sunflower oil}

Chemical shifts of proton signals of the compounds were determined by the chloroform signal ( $\mathrm{CHCl} 3, \delta=7,26 p . p$. $\mathrm{m}$.), which was present as an impurity in the deuterized solvent. In the area of 5,25,4 p.p.m. signals of olefin protons and metine proton of glycerol residue were observed; 4,1-4,3 p.p.m. - range of chemical shifts of methylene protons of glycerin; 2,6-2,8 p.p.m. - methylene protons $\mathrm{CH}=\mathrm{CHCH} 2 \mathrm{CH}=\mathrm{CHresidues}$ of linoleic and linolenic acids were absorbed; about 2,3 p.p.m. - all methylene protons located next to the carboxyl group; approximately 2,0 p.p.m. - all methylene protons near double bonds; about 1,6 p.p.m. - the following methylene protons; $1,2-1,4 \mathrm{~m}$. - range of chemical shifts of all remaining methylene protons; about 0,94 p.p.m. - methyl protons of linolenic acid, located next to a double bond; 0,8 $0,9 \mathrm{~m}$. - range of chemical shifts of all methyl protons, except linolenic. TheNMRspectrumis ${ }^{13} \mathrm{Cmuchmoreinfor}$ mative.

Figures 3-5 show fragments ofNMR spectra ${ }^{13} \mathrm{C}$ a combination of vegetable oils based on sunflower oil and forest berries proposed for use as the basis of a biologically active additive. 
Біологія, біотехнологія, екологія Айдарханова Г. С., Сатаева Ж. І., Ебель А. В., Джаканова М., Волосянко О. В., Сейлханов Т. М.

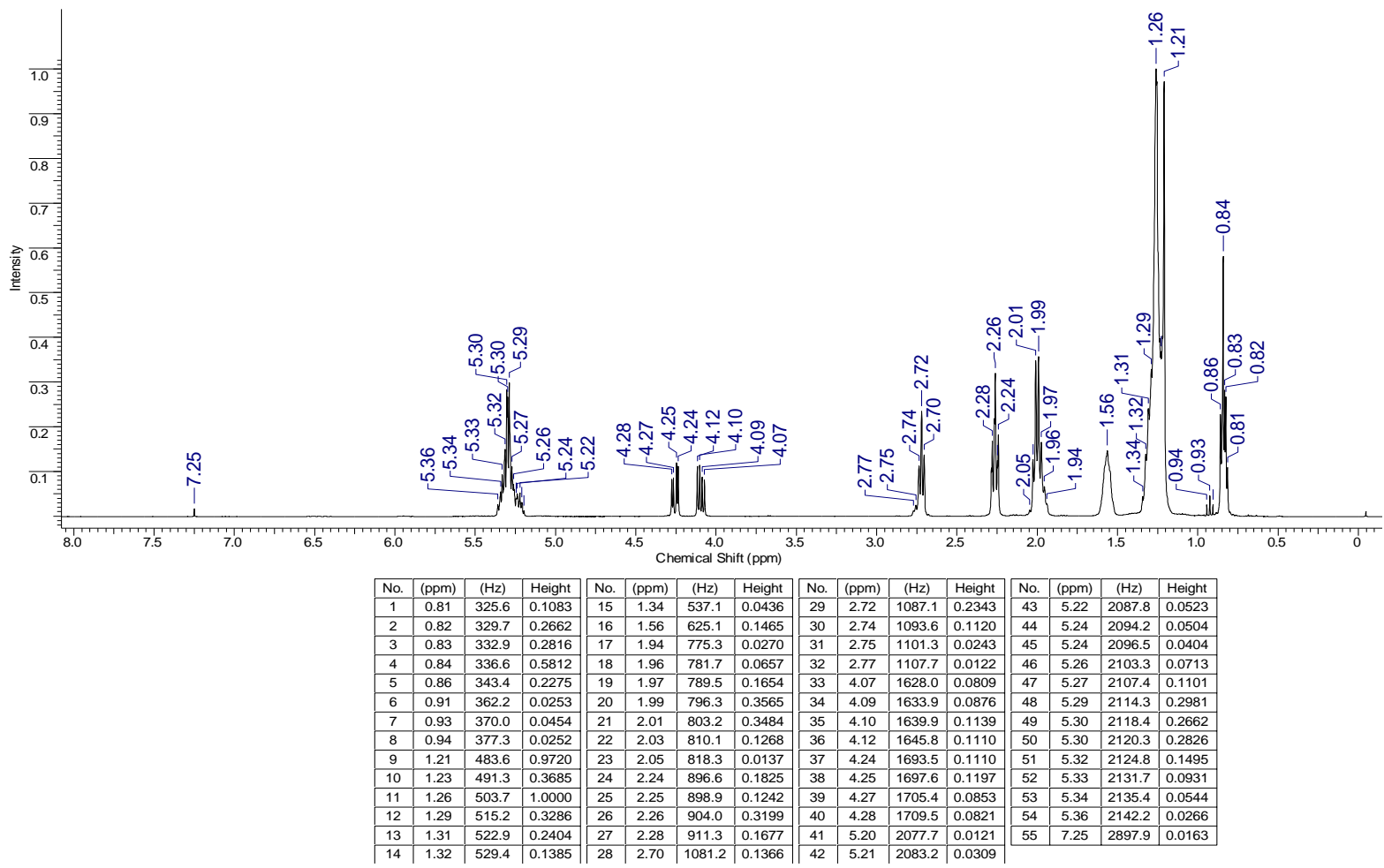

\section{Figure3 - 1HNMR -spectra of sunflower oil with rosehips}

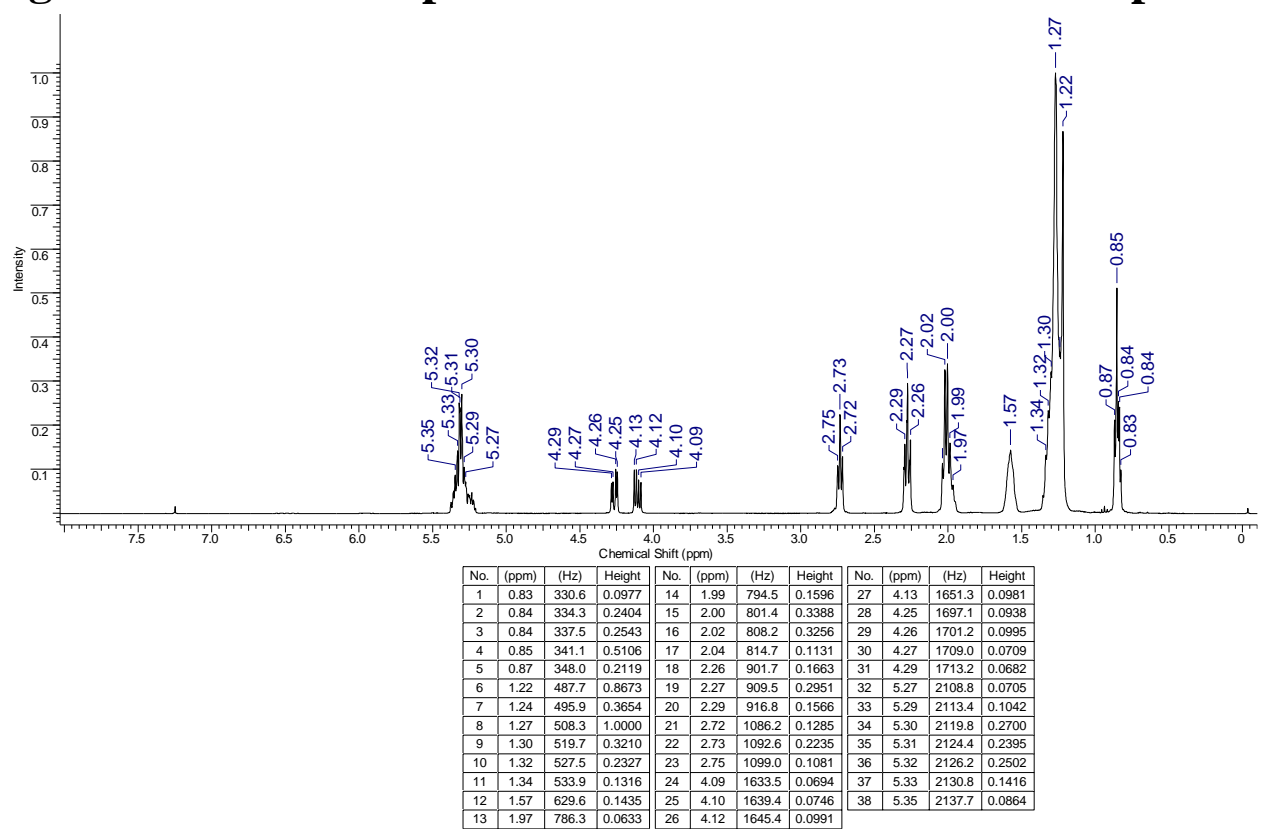

Figure 4 - 1HNMR -spectra of sunflower oil with blueberries 


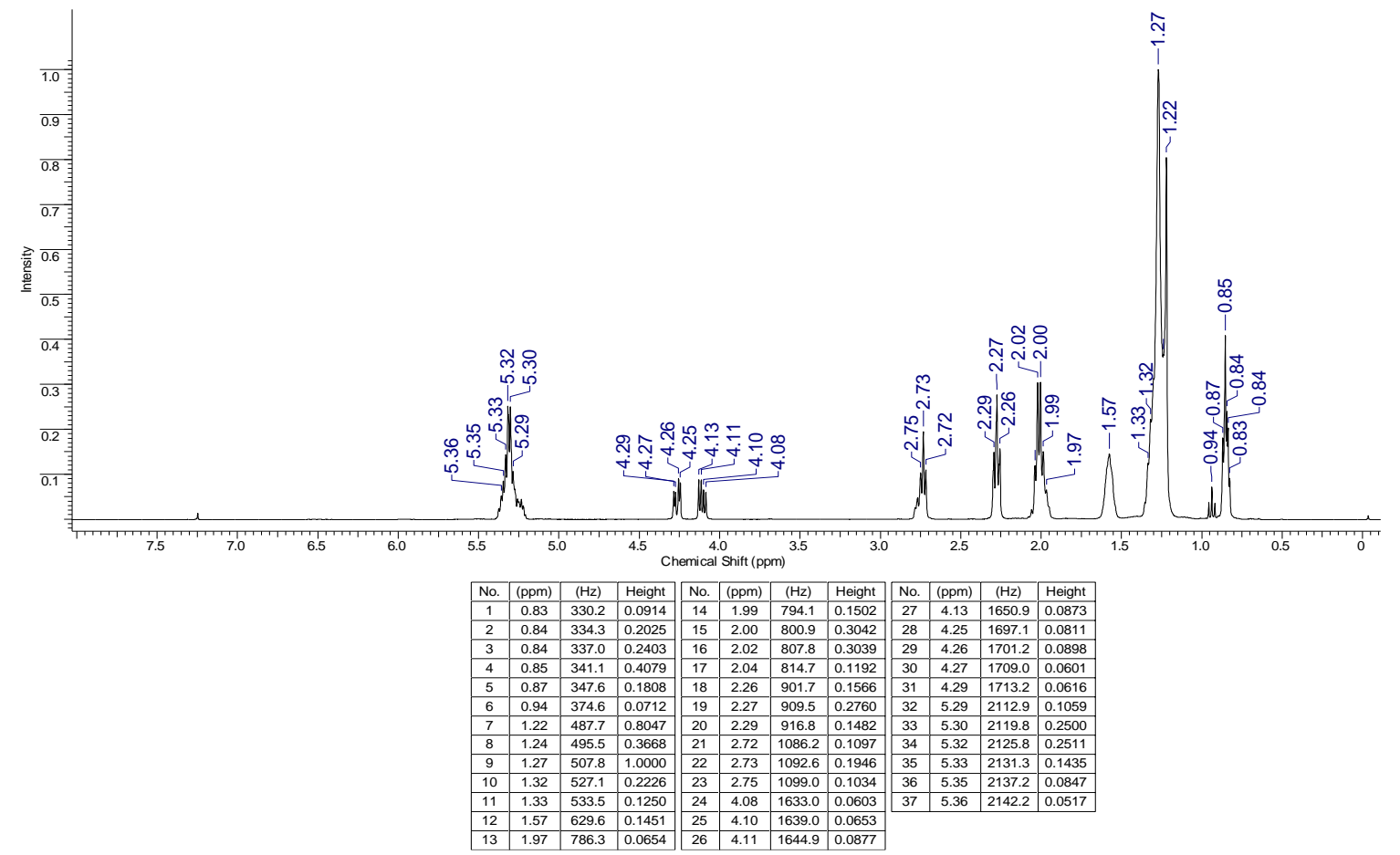

\section{Figure 5 - 1HNMR-NMR -spectra of sunflower oil with sea buckthorn}

As can be seen from the data obtained (Figures 2, 3, 4, 5), the signal ratio of all fatty acids changed significantly on the spectra. Changes are clearly visible on the spectra of lenolenic acid, showing its intensity. As you see from sunflower oil spectrum fragments (Fig.2), the most intense are linolenic acid signals $(127,7 ; 128,3 ; 128,8 ; 130,7$; 132,4 p.p.m.) - the main ones in this form of oil. Linoleic signals $(128,5 ; 130,6$; 130,8 p.p.m.) and oleic (130,2; 130,6 p.p.m.) of acids are less intense.

Conclusion. Sunflower and linseed oils obtained from seeds by the "cold squeeze" method were studied to assess quality and food safety among vegetable oils.

Studies of the physicochemical indices of sunflower oil and oil mixtures with the addition of forest berries: density, refractive index, acid number, peroxide number, iodine number and saponification number also meet the requirements of regulatory documents and characterize sunflower oil as a valuable food product. Wild berries (Elaeagnu srhamnoides (L.) A. Nelson, Rosa majalis Herrm., Vaccinium myrtillis L.), selected from the forest areas of northern and eastern Kazakhstan, are environmentally safe and can serve as a high-quality food additive in oil mixtures. In all berries samples, significant concentrations of heavy metals and radionuclides were not noted. The biological value of vegetable oils with additives is due to the content of polyunsaturated fatty acids in them. NMR spectroscopy confirmed that the optimal ratio of $\omega-6$ and $\omega-3$ polyunsaturated fatty acids in the composition of the studied vegetable oils correspond to their name in the ratio of monounsaturated and polyunsaturated fatty acids.

Thus, the composition of sunflower oil and its derivatives with wild berries 
Айдарханова Г. С., Сатаева Ж. І., Ебель А. В., Джаканова М., Волосянко О. В., Сейлханов Т. М.

was studied in detail by NMR spectroscopy. It was shown that the use of these methods allow to significantly detail the results of qualitative and quantitative analysis. NMR spectroscopy confirmed the optimal ratio of $\omega-6$ and $\omega-3$ polyunsaturated fatty acids in the obtained combinations of vegetable oils. The developed berrysunflower combinations of vegetable

\section{Reference}

1. Dolgolyuk I.V., Tereshyuk L.V., TrubnikovaM.A., Starovoytova K.V. (2014) Vegetable oils - functional food stuff. Technique and technology of food production. №2. P.122-125.

2. FAO (2001). Global Forest Resources Assessment 2000.FAO Forestry Paper 140. Rome, Italy.

3. Forest Europe (2015) State of Europe's Forest 2015 Report. http://foresteurope.org/state-europes-forests2015-report/\#1476293396492-81c050970e949acd-b805

4. Explanatory note to the materials of the state accounting of the forest fund of the Republic of Kazakhstan by January 2018. RGKP "Kazakh Forestry Enterprise": Almaty. 2018. 109 p.

5. Zhandybaev K. Oil and fat industry of Kazakhstan: state support, development and risku.

https://strategy2050.kz/ru/news/maslozhirovay a-otrasl-rk-gospodderzhka-razvitie-i-riski-/

6. Kazakov E. Yu., KlindukhovaYu. O., Shmalko N. A., Roslyakov Yu. F. (2004) New types of vegetable oil compositions with increased biological efficiency//Modern knowledge-intensive technologies. №2. P. 152153

7. Toropova E. Yu., Khovalyg N .A. (2014). Ecological assessment of habitats and fruits of sea-buckthorn in Republic Tyva. Fundamental research. №11. P.1732-1735.

8. Afanasyeva L. V., Kashin V .K. (2015). Accumulation of heavy metals in the fruits of HippophaerhamnoidesL. (Elaeagnaceae) in a roadside zone (Republic of Buryatia). Plant Resources. Issue. 4. P.554-561 oils with optimized ratio $\omega-6$ and $\omega-3$ of polyunsaturated fatty acids can be used in creating biologically active additives based on vegetable oils.

Research carried out within the framework of the project on grant financing of the Ministry of Education and Science of the Republic of Kazakhstan (project AR 05136154, 2018-2020)

9. Milinković M., Paunović S., ĐorđevićM., Tomić J., KaraklajićStajić Ž., Vranić D. (2019). Content of $\mathrm{Cu}, \mathrm{Zn}, \mathrm{Co}, \mathrm{Ni}, \mathrm{Cr}$ in soil and fruits of Apple and Plum //Book of Abstract $X$ Inter. Scientific Agriculture Symposium "AGROSYM 2019". Jahorina, October 03-06, P.909-915

10. Grigoryev S.V., Shelenga T.V., Illarionova K.V. (2019). Hempseed and cottonseed oils in the accessions from the VIR collection as sources of functional food ingredients. Proceedings on applied botany,genetics and breeding. 180(2):38-43. DOI: $10.30901 / 2227-8834-2019-2-38-43$

11. Shaka A. J., Keeler J. (1987). Broadband spin decoupling in isotropic liquids. Prog. Nucl.Magn.Reson.Spectrosc. Vol. 47, no. 19. P. 129-134.

12. Solladie-Cavallo A. [et al.] (2003). Linseed oil and mixture with maleic anhydride: $1 \mathrm{H}$ and 13C-NMR. J. Amer. Oil Chem. Soc. Vol. 80, no. 4. P. 311-314.

13. Popov K. I. (1999). The use of nuclear magnetic resonance spectroscopy for the express determination of the content of unsaturated fatty acids in vegetable and animal fats//Healthy food industry - 3 millennium: man, science, technology, economics: abstracts of reports of the International Scientific and Practical Conference, Moscow, February 2425. Publishing House of MSUFI. Moscow, P. 233-234.

14. Klimova N.S., Rykov R.S., Kalabin G.A. (2004) Possibilities of NMR spectroscopy in the identification of vegetable oils with therapeutic and dietary properties. Current problems of ecology and environmental management. № 5. P. 236-240. 
Айдарханова Г. С., Сатаева Ж. І., Ебель А. В., Джаканова М., Волосянко О. В., Сейлханов Т. М.

15. Ukraintseva I.I. (2004). Development of methods for quality assessment and identification of flax seeds based on nuclear magnetic relaxation method: extended abstract of Candidate of Technical Science: 29.03.05. Krasnodar, 23p.

16. Senouci H. (2000). Quantitative analysis of partial acylglycerols and free fatty acids in palm oil by ${ }^{13} \mathrm{C}$ nuclear magnetic resonance spectroscopy. J. Amer. OilChem. Soc. Vol. 77, no. 7.P. 749-755.

17. GOST 31214-75 Vegetable oils. Production.Terms and definitions.

18. Bykov B.A. (1970). Introduction to phytocenology. Alma-Ata: Publishing houseAHKazSSR, $226 \mathrm{p}$.

19. ST RK GOST R 51301-05. Atomic absorption spectroscopy methods.

20. Methodological instructions 2.6.1.717-98 Radiation monitoring. Strontium90 and caesium-137. Food products. Sampling, analysis and hygienic assessment. Methodological guidelines on control methods. M.: Science, 1977. 51 p.

21. Sanitary Rules and Norms of the Republic of Kazakhstan, No. 611 Order of the Ministry of Health of the Republic of Kazakhstan dated 20.06.2011 Astana. 2011
22. Subbotina M.A. (1999). General methods of analysis of vegetable oils and fats. Laboratory workshop. Kemerovo.- page 5.

23. GOST ISO 6320-2012 Fats and oils animal and vegetable. Refractive index method.

24. GOST 31933-2012. Vegetable oils. Methods for determining acid number.

25. GOST 5475-69 Vegetable oils. Methods for determining iodine number.

26. GOST ISO 3657-2016 Animal and vegetable fats and oils. Determination of saponification number.

27. National report of the Republic of Kazakhstan on biological diversity//Report of Program 001 "Ensuring the activities of the authorized body in the field of environmental protection." - State Registration No. O.0411. Astana, 2010. 142 p.

28.Sultangazina G.J., KuprijanovA.N., KuprijanovO.A., Beyshov R.S. (2020). Coenoflora of Adonis Vernalis L. in Northern Kazakhstan. Bulletin of National Academy of Sciences of the Republic of Kazakhstan.Volume 1, Number 383, 33-41 https://doi.org/10.32014/2020.2518-1467.4

29. Karamysheva Z.V., Rachkovskaya E.I. (1973). Botanical geography of the steppe part of Central Kazakhstan. L.: Science. 278 p.

\section{ОЦІНКА ЯКОСТІ ТА ХАРЧОВОЇ БЕЗПЕКИ РОСЛИННИХ ОЛІЙ, ОТРИМАНИХ НА ОСНОВІ ДИКОРОСТУЧИХ ЯГІД ЛІСОВИХ ТЕРИТОРІЙ КАЗАХСТАНУ \\ Г. С. Айдарханова, Ж. І. Сатаева, А. В. Ебель, М. Джаканова, О. В. Волосянко, Т. М. Сейлханов}

Анотація. Багато видів лісових рослин у комплексі з рослинними оліями є джерелами нових видів функиіональних продуктів з підвищеною біологічною ефективністю. 3 огляду на високий попит на рослинні олії серед населення $i$ промисловості, наростаючий антропогенний пресинг на різні компоненти природного середовища, метою досліджень є створення олійних сумішей на основі соняшникової олії $і$ дикорослих ягід, відібраних на лісових територіях регіонів Казахстану, оцінка їх якості та харчової безпеки. Основою олійної суміші стало соняшникова олія, отримана з насіння соняшнику методом «холодного віджиму». Як біодобавки використані дикорослі ягоди, відібрані на лісових територіях північного (Elaeagnus rhamnoides (L.) A.Nelson) i східного (Rosa majalis Herrm., Vaccinium myrtillis L.) Казахстану. В отриманих олійних сумішах були вивчені базові показники їх якісно-кількісного складу. Встановлено, щзо за щільністю (917-918), показником заломлення (1,473), значенням 
Айдарханова Г. С., Сатаева Ж. І., Ебель А. В., Джаканова М., Волосянко О. В., Сейлханов Т. М.

кислотного числа (1,4 мг КОН/2), йодного числа (130-132гJ2/100), числа омилення (188 мг/2) досліджуваних олійних сумішей вони відповідають нерафінованій рослинній олї вищзого сорту.

Вміст важких металів (Pb, $\mathrm{As}, \mathrm{Cd}, \mathrm{Cu}, \mathrm{Zn}, \mathrm{Mg}$ ) і радіонуклідів (90Sr, 137Cs) не перевищує гранично допустимих кониентращзій $i$ відповідає вимогам нормативних документів $і$ стандартів. У пробах рослинних олій визначені кількість олеїнової кислоти (52,21\%), лінолевої кислоти (28,97\%), які знаходяться в межах норми, хоча досягають до рівнів верхніх меж. Методом ЯМР-спектроскопї підтверджено, щуо оптимальне співвідношення $\omega-6$ i $\omega-3$ поліненасичених жирних кислот у складі вивчених рослинних олій відповідають своїи назві по співвідношенню мононенасичених $i$ поліненасичених жсиних кислот.

Ключові слова: дикорослі ягоди, sunflower oil, unrefined oils, важкі метали, paдіонукліди, physicochemical parameters, fatty acid composition, NMR spectroscopy, spectra, proton signals 